\title{
Ethics and Integrity in the Procurement of Goods and Services for the Military
}

\author{
David Fourie \\ University of Pretoria
}

Public service ethics and integrity strengthen public trust and good governance, underpinning public servants' responsibility to exercise stewardship, and to use and develop all resources in the most economical, efficient, and effective way. Pure military procurement requires a sensitive procurement approach, subject to a regulatory system that acknowledges military confidentiality, striking a balance between openness and transparency in the military procurement process and protection of core security concerns of the procuring state. Ethics refers to established standards of right and wrong that prescribe what people ought to do, in relation to duties, principles, specific virtues, or benefits to society. For military staff as public administrators, ethics begins with and is grounded in duty. From an ethical perspective, there is a need for an overarching framework of moral values and ethical principles, which should have a significant and sustainable impact on the creation of public value as an outcome of military procurement processes. In the military procurement process, networks of deliberation and delivery in pursuit of public value require thoughtful and open-minded relationships with a commitment to a strong public service ethos. A sound ethical framework enables a public sector environment that encourages high standards of professional ethics and integrity in military procurement.

Keywords: accountability and military procurement, ethics, governance, integrity, public administration, stewardship

Public administration, as part of the executive branch of government, is an element of state power. It consists of departments, agencies, ministries, and other structures jointly referred to as "public administration." Public administration generally combines all activities, including military activities, concerning the public good and public interest. In the administrative government environment, there are public administrators, unique administrative procedures, and many other mechanisms characteristic of all bureaucratic organizations.

The public service is a public trust, so public administrators must provide services in aid of a country's citizens. This effort is based on public funds and other assets, so there is a possibility of betraying public trust. Ethical behavior and decisions to warrant citizens' trust ensure effective and efficient use of resources, and allow government to preserve individual rights while assisting those who will benefit the most. Ethics and integrity provide standards of conduct that are vital components for democracy to thrive in any country.

Correspondence should be sent to David Fourie, School of Public Management and Administration, University of Pretoria, Lynwood Road, Hatfield, Pretoria 0002, South Africa. E-mail: prof.djfourie@up.ac.za 
Public service ethics and integrity are prerequisites for public trust, and are the keystone of good governance that transcends the conventional boundaries of public administration. Governance encompasses the traditions, institutions, and processes that determine how public authority is exercised, how citizens are given a voice, and how decisions are made on issues of public concern. Governance speaks to how society actually makes choices, allocates resources, and creates shared values; it deals with societal decision-making and the creation of meaning in the public sphere.

Good governance is a form of governance that displays characteristics such as accountability, willingness to reach consensus, effectiveness and efficiency, equity and inclusiveness, participation, responsiveness, obedience to the rule of law, and transparency. These characteristics underpin public servants' responsibility for stewardship to use and develop all resources, including the country's people and its financial assets, in the most economical, efficient, and effective way possible. From an ethical perspective, stewardship can also be seen as a function of government, which is responsible for the welfare of a country's population, and which is concerned about the legitimacy of its activities and the trust of its citizens.

The aim of this article is to contextualize procurement in the South African public sector, and to reflect on the state's susceptibility to engage in unethical conduct when procuring goods and services. The article also considers military procurement as a critical component of the defense logistics system. In the South African case, specific attention is devoted to the South African Strategic Arms Package (SAP), which has attracted criticism related to unethical conduct. The method of study used in this article is a qualitative analysis, investigating and reviewing relevant literature, legislation, and policy documents that reflect military procurement in South Africa, using the SAP as a case study. The article aims to:

- reflect on the literature of public procurement and the legislative framework regulating public procurement in South Africa;

- examine ethics and integrity in the context of military procurement;

- discuss the South African SAP as a case that attracted fierce, sustained criticism regarding unethical conduct; and

- suggest a framework to guide ethical conduct to ensure high standards of professional ethics and integrity in military procurement.

\section{Context of procurement in the public sector}

Public administration refers to the combination of all activities concerning the public good and public interest in the management of scarce resources to accomplish the goals set by public policy. As a subdiscipline of public administration, public financial management is recognized as a discipline and profession that plays a key role in the successful management of public resources. Public finance literature indicates that governments engage in four main economic activities: first, providing a legal framework for all economic activities; second, redistributing income through taxation and spending; third, making public goods and services freely available to the public by providing national defense, public safety, education, and infrastructure; and fourth, purchasing goods, services, and capital assets (Jordaan, 2013, p. 64).

Public finance management includes resource mobilization, prioritization of programs, the budgetary process, efficient management of resources, and exercising controls. Public 
procurement is increasingly recognized as an integral aspect of prudent public financial management, aligned with the field's traditional functions and issues. However, public procurement is vulnerable to mismanagement and corruption. This vulnerability imposes a need for stewardship in public administration. It underlines the relationship between the public administration environment, value for money (measured in terms of economy, efficiency, and effectiveness), and the application of good-governance principles in order to enhance public financial performance (Jordaan, 2013, p. 27).

In a public administration context, procurement refers to the activity of buying goods and services for government departments. According to Roodhooft and Abbeele (2006, p. 494), public bodies have always been big purchasers, with very large budgets. Rolfstam (2009, p. 349) claims that public procurement can amount to $16 \%$ to $18 \%$ of a country's GDP. In absolute numbers, all governments worldwide spend US\$9.5 trillion every year on public procurement. In developing countries, public procurement is increasingly recognized as essential in service delivery (Davis, 2014, p. 79), and it accounts for a high proportion of total expenditure. However, this function is vulnerable to corruption, inefficiency, and mismanagement.

"At least $42 \%$ of South Africa's national budget is spent on the acquisition of goods and services" (Chipkin, Tshimomolo, \& Brunette, 2014, p. 18). This percentage is exorbitant in terms of the overall national budget. Public expenditure continues on a large scale in South Africa, but this appears to be necessary. In 2013/2014, the South African public sector spent ZAR500 billion (43.51\% of the total budget) on goods and services and on construction work. This money, if it is wisely and efficiently spent, can contribute enormously to service delivery. It can ensure that citizens receive basic services (water, electricity, and sanitation) and that infrastructure (such as roads and ports) is built and maintained, that schools are well equipped, and that health services are widely available. It can also spread wealth to hard-working entrepreneurs who successfully tender for government contracts and, in doing so, create jobs. Those not directly involved in the public sector supply chain can also benefit, as suppliers to government source their supplies and materials from manufacturers, farmers, and others (RSA, National Treasury, 2015, pp. 3-4).

More than 80 different legal instruments govern public sector procurement in South Africa (RSA, National Treasury, 2015, p. 10). All these laws and regulations relating to public procurement are implemented through a large number of independent statutory instrumentssome cater for specific procurement practices, and others for particular sectors or industries. The regulatory framework governing procurement pertains to all key legislation, which provides the cornerstone for managing procurement processes. The relevant legislative prescripts are used as a first point of reference in implementing procurement, and in related aspects of openness and transparency in all organs of the state. The legislation that forms the basis of the South African procurement regulatory framework (Fourie, 2015, p. 39) includes the Constitution of the Republic of South Africa, 108 of 1996 (RSA, 1996a), the Public Finance Management Act, 1 of 1999 (PFMA) (RSA, 1999a), the Preferential Procurement Policy Framework Act, 5 of 2000 (PPPFA) (RSA, 2000a), the Preferential Procurement Policy Framework Regulations (RSA, 2001), the Municipal Finance Management Act, 56 of 2003 (MFMA) (RSA, 2003) (MFMA), the Model Policy Municipal Supply Chain Management (RSA, 2005a), and the Municipal Supply Chain Management Regulations of 30 May 2005 (RSA, 2005b), as well as the South African National Treasury prescripts, namely, the Policy to Guide Uniformity in Procurement Reform Processes in Government (RSA, National 
Treasury, 2003), the Treasury regulations promulgated on 15 March 2005, and various Treasury guidelines, circulars, and practice and instruction notes.

The management of a public institution's procurement function is susceptible to a wide variety of real everyday risks (Fourie \& Opperman, 2011, p. 35). There are risks of collusion, fraud, bribery, unethical interference, and the likelihood that procurement may not protect the best interests of the procuring entity if the procured goods and services are not cost-effective and value for money. Tukamuhabwa (2012, p. 34) points out that public procurement "has become an issue of public attention and debate, and has been subjected to reforms, restructuring, rules and regulations." The decision to award a tender constitutes administrative action, as it needs to follow the provisions of the Promotion of Administrative Justice Act, 3 of 2000 (PAJA) (RSA, 2000b).

The Defence Review (RSA, Department of Defence, 2014, pp. 14-16) states that the defense procurement system is a critical component of the defense logistic system; hence, it is a key resource area that contributes to effective, efficient, and transparent spending of the defense budget. Procurement policy and doctrine should be informed by the defense mandate, goals, and tasks. The defense procurement policy and doctrine should be based on higher-order defense policy and doctrine, and must deliver a single, robust, comprehensive, inclusive, transparent procurement process. Moreover, the defense procurement system must be capacitated and capable of delivering a defense procurement policy and doctrine.

The Defence Review (RSA, Department of Defence, 2014) defines defense procurement as the complete process of acquiring or obtaining personnel, equipment, services, or property from outside the South African National Defence Force (SANDF), by means authorized in pertinent directives, in support of operational requirements. It includes negotiating, contracting, and purchasing. Defense procurement must be managed in the manner prescribed in the PFMA (RSA, 1999a) (as amended), and the Treasury regulations (as amended). Defense procurement is specifically responsible for establishing a single, comprehensive, tailorable, and robust procurement system capable of delivering fair, competitive, transparent, equitable, and costeffective procurement support to both internal and external operations, in accordance with defense combat service support doctrine. It has to ensure that goods and services are procured and made readily available for defense officials to perform their respective roles, and has to dispose of inventory no longer required. Only designated defense officials may be authorized to procure and are responsible for procuring the required goods and services and/or selling goods no longer required (RSA, Department of Defence, 2014, pp. 14-16).

The Defence Review (RSA, Department of Defence, 2014, pp. 14-19) states that the defense procurement long-term priorities are to implement best practice military procurement management, founded on a single integrated procurement management information system that includes the migration requirement to accrual accounting, the establishment of the defense procurement regulatory framework, and the elimination of all adverse audit findings in the defense procurement environment.

There is a distinction between "general" procurement and "pure military" procurement. Pure military procurement requires a more sensitive procurement approach subject to a regulatory system that acknowledges military confidentiality, and strikes a balance between the openness and transparency of the procurement process, on the one hand, and the protection of the core security concerns of the procuring state, on the other hand. This article focuses on pure military procurement, which, because of the nature and intended use of the material 
procured, is closely linked to the notion of defense and security (RSA, Department of Defence, 2014, pp. 14-16).

Military procurement as a contracting process and as a commitment based on human decision-making often attracts negative public opinion. Many argue that too little effort is made to curtail waste and excess spending. There is an ongoing debate concerning quality versus quantity in procurement. Citizens expect fair and reliable public services from public servants that inspire public trust, serve the public interest with fairness, and manage public resources properly on a daily basis. The effective operation of democratic government requires public officials and employees to be independent, impartial, and responsible to the people. Government decisions and policies should be made within the proper structure of government, public office may not be used for personal gain, and the public has to have confidence in the integrity of its government. When ethical wrongdoing and scandals occur in government, they pose a threat to the democratic principles of the rule of law, equity, and individual rights (Kazman \& Bonczek, 1999, p. 2).

\section{Ethics and integrity in relation to military procurement}

Generally, ethics is "a set of principles, often defined as a code or system that acts as guide to conduct" (Lawton, 1999, p. 299). Ethics is a universal concept central to human existence, and it relates to the notions of good and evil inherent in all communities (Singer, 2011). In the most elementary sense, ethics is a set of values and rules that define right and wrong behavior (Hellriegel et al., 2008, p. 108). These values and rules indicate when behavior is acceptable, and when it is not. In a broader sense, ethics includes distinguishing between facts and beliefs, defining issues in moral terms, and applying moral principles to a situation.

Moral principles and the values that they present are fundamental to ethics. Some moral principles concerning managerial and employee behavior are widely shared, but others are not (Sims, 1994, p. 83). Many professions have ethics codes; for example, psychologists, the police, intelligence agents, lawyers, and doctors. Many defense forces also have an "ethics" code, in the form of a code of conduct. But what really constitutes military ethics? Arguably, the military by definition makes war-what is ethical about fighting wars?

A key question regarding military ethics asks why ethics matters to the military at all, and whether formal ethics programs are necessary or productive. In this context, what is meant by military ethics? Does it refer to instilling a general morality in military personnel that makes them what an ordinary civilian might consider "morally good"? Or does it refer more narrowly to the professional standard required for the fulfillment of their role as service members? Is it actually necessary for military personnel to be morally good, as long as they are proficient at their jobs? Are the two issues separable, or are they mutually dependent? In short, is the ethics required of soldiers in their role (role morality) the same as that required of civilians (ordinary morality)?

Military ethics can be defined as an ethics relating to the nature, content, validity, and effect of morals in a military context (Van Baarda \& Verweij, 2006, p. 2). Thus military ethics refers to both the conceptual creation of scientific theory and applied ethics casuistry (Tripodi \& Wolfendale, 2011, p. 22). Van Baarda \& Verweij (2006, p. 3) distinguish five layers of military ethics, namely a personal value system, ethics of the military profession, ethics of particular 
professionals within the military (e.g., psychologists, doctors, lawyers, and social workers), organizational ethics (which sets standards for the military organization and its personnel), and political ethics (which sets standards of propriety on the circumstances under which units of armed forces may be sent on a mission by the political leadership). In the military, "ethics" is often used synonymously with "integrity" but these two terms denote completely different constructs.

There are two main forms of loyalty as an aspect of ethics, namely loyalty to a group (which can range from one's primary group to one's country) and loyalty to a principle (such as justice, or respect for human life) (Olshoorn, 2011, p. 11). Although militaries have a propensity to the first form, group loyalty, most philosophers and ethicists focus on loyalty to a principle, and they have a point - group loyalty tends to require the suspension of independent judgment, but loyalty to principle, on the whole, does not. However, it is not clear where these principles should stem from. It seems obvious to look for these principles outside oneself-in a moral tradition, religion, or the values espoused by society—but some believe that the highest form of loyalty is loyalty to the principles and values one finds in oneself. This loyalty to one's own principles and values is often denoted by the term "integrity."

Integrity is defined by the Organisation for Economic Co-operation and Development (OECD, 2009, p. 19) as "the use of funds, resources, assets and authority, according to the intended official purposes, to be used in line with public interest." Amundsen (2009, p. 23) adds that it involves "having a sense of honesty and truthfulness in regard to the motivations for one's actions," and that corruption is the antonym of integrity. There is no doubt that integrity, as the requirement consistently to give precedence to ethical values in decisions and actions, enjoys privileged status. Integrity is the crucial component of identity, both for a person and an organization. It necessarily and immediately refers to values such as honesty and fairness, to the reliability and trustworthiness that are intrinsic to loyalty, and to the exercise of responsibility in difficult situations (OECD, 2009, p. 19).

Notwithstanding the profusion of meanings, the term "integrity" has a restricted connotation in most organizations. It is mainly negatively formulated, in that it is concerned with the things an employee should not do; for example, taking gifts of a value above a certain threshold, being careless with sensitive information, or taking office supplies home for private use. Clearly, this is not what integrity as a virtue is about, nor what, for instance, most militaries take it to be, although this narrow definition of integrity is very much alive in most armed forces too.

In general, however, integrity as a virtue has a wider meaning, although this meaning is somewhat hard to pin down. According to one military ethicist, integrity is a "much-used term but very much in need of analysis" (Wakin, 2000, p. 115). It can, for instance, stand for "wholeness," which is actually closest to its original meaning (the Latin adjective integer means "whole" or "complete"). Being just, for instance, does not mean much if you lack the courage to defend it, and courage is of not much use without practical wisdom to guide it. The unity of the virtues also suggests that one cannot be a moral person in one sphere of life and wanting in morals in another. Related to this description of integrity is the view that integrity is consistent over time; integrity can also be seen as being steadfast, and not giving up beliefs under pressure. At the same time, complicating matters somewhat, some hold that integrity can also demand that we balance and reassess our principles and values in the light of new circumstances (Cox, La Caze, \& Levine, 2003, pp. 2-5, 17, 41). 
To circumvent these definitional subtleties, the phrase "possessing integrity" is often used simply as synonymous with "being ethical" (Cox et al., 2003, p. 56). This is the meaning it appears to have when a military organization lists it as a principal virtue or value; an ethical person is then seen as someone who possesses the virtue of integrity to the extent of personally upholding moral principles. Although upholding moral principles is a good thing, it does not help us understand what this virtue is about. In all likelihood, integrity is located somewhere between the narrow definition of integrity as conforming to organizational rules and the all-too-wide definition that equates it with ethical behavior. Essentially, if one seeks the meaning of the term in its everyday use, integrity can be taken to mean something like living by, and being loyal to, our own values and principles; in other words, as "being loyal to ourselves." This in turn suggests that we have moral obligations, not only to others, but also to ourselves, and especially an obligation to live in accordance with our own moral principles.

A basic model of the decision-making process is a useful tool to assist in resolving difficult situations in administration containing ethical components. Using such a model contributes to the completeness of analysis and increases the consistency of decision-making in a military procurement process. There is a strong emphasis on basic duties, the principles of fairness and legality, and the virtues of honesty and integrity. It seems appropriate to place duty at the core, in particular the commitment to serve the public and the obligation to put the interest of the public above personal self-interest (Pauw \& Wolvaardt, 2009, p. 70).

The basic components of the interplay of duty, virtue, and principle(s) are presented in Figure 1.

In the military domain, integrity implies consistent alignment of moral awareness, discerning what is right and what is wrong. It requires balanced judgment and action consistent with such judgments. It also requires a sustained exercise of ethics in the organization, and in all organizational practices, including military procurement. To maintain a healthy sense of ethical wholeness, integrity implies the practice of explaining openly and publicly why particular actions have been taken and why particular policies are in place. Integrity is absolutely essential for group cohesion; it feeds the courage required to take action in the face of physical and moral challenges in decision-making (Kem, 2006, p. 22).

An analysis of the ethical component of principle reveals that ethics is an external system of rules and laws. Usually there are rewards for following the rules, and punishments for not following rules. Normally, it is possible for a professional body to monitor and determine compliance with rules. Like the military profession, many organizations have developed codes of ethics that employees are expected to obey (Rossouw \& Van Vuuren, 2007, pp. 2-6). The ethical component of virtue, on the other hand, is an internal system of integrity that guides human behavior. Integrity is a choice rather than an obligation, and the rewards are intrinsic. Even though integrity is influenced by upbringing and exposure, it cannot be (en)forced by

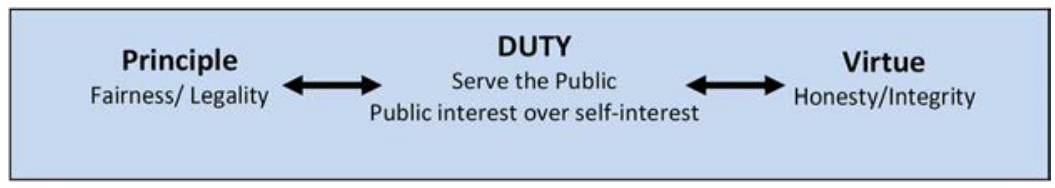

Figure 1 Basic components of administrative ethics. Source: Pauw \& Wolvaardt, 2009, pp. 66-88. 
outside sources. It conveys a sense of wholeness and strength. When you act with integrity, you do what is right even when no one is watching (Robbins, 1997, p. 87). People of integrity are guided by a set of core principles that empower them to behave consistently, meeting high standards. The core principles of integrity are the virtues of compassion, dependability, generosity, honesty, kindness, loyalty, maturity, objectivity, respect, trust, and wisdom. Virtues are valuable personal and professional assets that military professionals develop and display in their actions (Rossouw \& Van Vuuren, 2007, pp. 2-6).

From the above discussion on ethics and integrity, it seems that there is a dynamic relationship between integrity and ethics, where each strengthens, or reinforces, the other. Personal integrity is the foundation for ethics. Sound administrative ethics encourages integrity. If you have worked hard to develop a high standard of integrity, you are likely to transfer these principles to your professional life. If you possess a high degree of integrity, your words and deeds will be in alignment with the ethical standards of the organization (Robbins, 1997, p. 87).

Ethics is about following the rules; integrity is about doing the right thing regardless of the rules. If your chief goal is to stay out of trouble once the rules have been spelled out, you could be ethical but still lack integrity. This does not mean you would refrain from certain acts if they were not prohibited. Integrity comes from a greater depth of character (Rossouw \& Van Vuuren, 2007, pp. 2-6).

\section{Military procurement: South Africa's strategic arms package}

The South African government's SAP is considered here as a case study. The SAP has been the source of one of the largest public controversies in post-apartheid South Africa. In 1999, the South African government entered into a strategic arms procurement deal of over ZAR29 billion (around US $\$ 3.98$ billion). The deal consisted of five main contracts for the acquisition of naval corvettes, submarines, air force fighters/trainer jets, and utility helicopters. These contracts were lumped together in a package intended to provide a more affordable deal for the South African government (Sylvester \& Seegers, 2008, p. 53). The packaging of the projects was intended to obtain maximum commercial and political leverage, and thus the largest armaments deal concluded in South Africa was created. The agreement focused on the acquisition of 28 Gripen Advanced Light Fighter Aircraft and 24 Hawk Lead-In Fighter Trainers from $\mathrm{BAE} / \mathrm{SAAB}$, four corvettes from a German frigate consortium, three submarines from a German submarine consortium, and 30 Agusta A109 helicopters from Italy. Given that most of the equipment had to be imported, the contract value of ZAR29 billion fluctuated as the ZAR fluctuated against the relevant currencies (Botha, 2010, p. 99).

To ensure transparency, the Ministry of Defence introduced a consultative process to obtain consensus regarding the nature and aim of the South African National Defence Force (SANDF), an initiative that was supported internationally. The views of all the interested parties culminated in a Defence White Paper (RSA, 1996b), The Defence Review Report (RSA, Department of Defence, 1998), and a White Paper on Defence Related Industries (RSA, 1999b), and the outcome of the process passed through the Parliamentary Portfolio Committee. A number of issues were covered, including the roles, structure, size, and shape of the Ministry of Defence and the SANDF. The primary role and tasks of the SANDF were defined as the defense of the territory of South Africa, as opposed to its prior preemptive force-projection role under the 
apartheid government. It was proposed that since there was no direct military threat to South Africa, the SANDF should fulfill its key missions, but could be increased if the need arose. In line with these White Papers, several force-design options were studied and presented to the South African parliament and cabinet for a final decision. Thus South Africa engaged in an open process in the design of its military establishment, considering many views on what was required. It is disappointing that, having followed this consultative path, the South African government is still criticized for its choices (Botha, 2010, pp. 99-100).

The "Arms Deal," as the package become known, has attracted fierce, sustained criticism from all quarters of South African society. Several concerns regarding irregularities in the decision-making process were investigated by the auditor-general, and a report was submitted in September 2000 to the Select Committee on Public Accounts (SCOPA). The report recommended that the public protector, the auditor-general, the Directorate Special Operations of the National Prosecuting Authority, and the Heath Special Investigations Unit undertake a detailed investigation of all aspects of the deal. Approximately 700,000 pages of documentation were scrutinized, and numerous interviews were conducted; the result was an allegation of possible corruption (Botha, 2010, p. 101). However, in April 2016, the Seriti Commission of Enquiry into the Strategic Defence Procurement Packages (SDPPs) found that there was no evidence of outside influence, bribery, or corruption in the SAP procurement process.

From an ethical and integrity perspective, the main debates revolve around two dimensions of the SAP, namely military necessity and affordability. Sylvester and Seegers (2008, p. 73) as cited in $\operatorname{OECD}$ (2011, p. 3) comment:

In the context of the heightened requirement for confidentiality in strategic and security imperatives, and the complexity of the subject matter, a differentiated procurement approach seems to be applied in the field of defense that departs from general standards of openness and transparency usually required in public procurement. The degree of departure from the general standards of openness and transparency appears to allow a wider than usual margin of discretion for contracting authorities, and provides fertile ground for integrity violations.

From an ethical perspective, it is clear that there is a need for an overarching framework of moral values and ethical principles to have a significant and sustainable impact on the creation of public value as an outcome of a military procurement process.

\section{Military procurement: a proposed ethical framework}

An overarching framework in support of value creation would rely on decision-making involving a wide range of participants who should be seen as legitimate members of the decision-making process, especially in the context of considerable uncertainty and complexity. The emphasis should be on finding new ways to collaborate as the interdependence of a range of individuals and organizations intensifies. Governance of the public administration environment involves networks of deliberation and delivery in pursuit of public value. Knowing whether public value is being delivered requires engagement and an exchange between all the relevant stakeholders and government officials. The fundamental idea is that for a decision to be legitimate, or for a judgment to be made, it is essential to engage with all the stakeholders. Networks of deliberation and delivery in pursuit of public value in military procurement require 
an open-minded relationship and approach characterized by a commitment to a public service ethos (Stoker, 2006, p. 50).

In support of ethical frameworks, the OECD has compiled a range of tools and processes as an ethics infrastructure regulating against undesirable behavior, and providing incentives to encourage good conduct by public officials. Eight key elements of an ethics infrastructure are listed, namely political commitment, an effective legal framework, efficient accountability mechanisms, workable codes of conduct, professional socialization mechanisms, supportive public service conditions, a central ethics coordinating body, and an active civil society. Each of the components of the ethics infrastructure performs one or more of three overlapping roles: controlling behavior, providing guidance to behavior, and/or managing other elements of the infrastructure. The importance of each of these elements and the relative synergy between them depends on the institutional and governance conditions and traditions of the public administration organization concerned (OECD, 2000, pp. 24-25).

Political commitment to ethical behavior is valued. It provides a mechanism for social coordination, and has the potential to influence cooperation by changing people's preferences and creating an environment in which partnerships are possible. A clear and consistent legal framework lies at the heart of an ethical framework. Laws and regulations define the basic standards of behavior for public servants, and enforce these standards through systems of investigation and prosecution. Accountability mechanisms should encourage ethical behavior by making unethical activities hard to commit and easy to detect. Accountability mechanisms thus set guidelines for government activities and internal administrative procedures.

Disoloane (2012, p. 92) argues that a code of conduct fulfills a primary function in combating unethical behavior on the part of public officials and political officeholders. The goal of such codes is to establish an ethical culture and high standards of integrity within departments and ultimately in the public service. Professional socialization mechanisms allow for better communication and inculcation of codes of conduct and legal provisions. Socialization mechanisms are processes by which public servants learn and adopt ethical norms, standards of conduct, and public service values. Supportive public service conditions, such as sufficient job security, opportunities for promotion and career development, fair remuneration, and social appreciation, are all elements that support the high standards of ethical conduct expected of public officials.

Ethics coordinating bodies might be parliamentary committees, central agencies, or specially created bodies working well within an active civil society, which includes assertive media that through their probing reporting help citizens to act as watchdogs over the actions of public officials.

A well-functioning ethical framework, as depicted in Figure 2, provides for a public sector environment which encourages high standards of professional ethics and integrity in military procurement. Each function and element is a separate but important building block. The individual elements should be complementary and mutually reinforcing. The elements need to interact to achieve the necessary synergy to become a coherent and integrated framework based on networked governance. The elements of the framework can be categorized according to the main functions they serve, namely guidance, management, and control. Note that different elements may serve more than one function (Kettl, 2002, p. 186).

In the analysis with reference to military procurement, guidance is provided by a strong commitment from political leadership, measures to ensure that efficient and accountable 


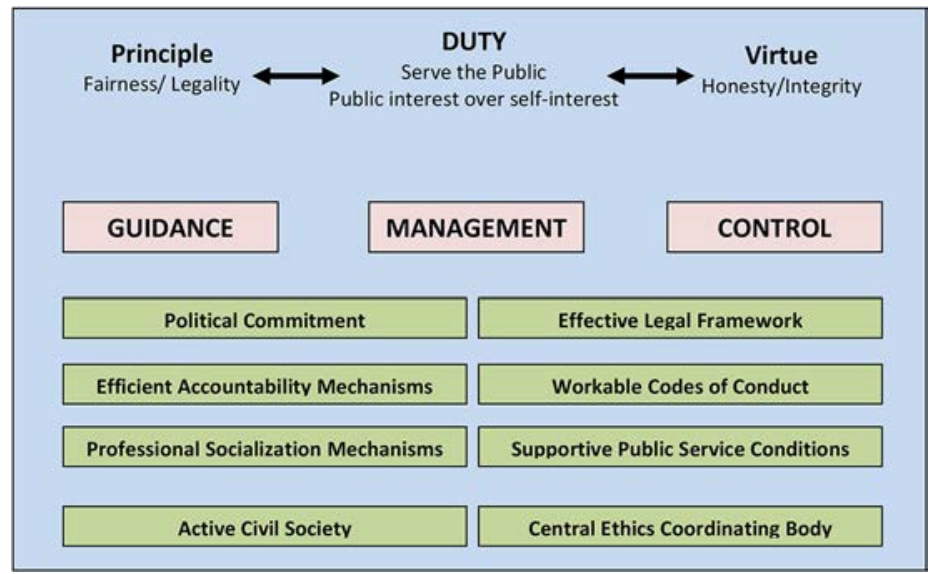

Figure 2 Suggested ethical framework. Source: Adapted from OECD, 2000, pp. 4-25.

mechanisms are in place, adherence to guidelines provided by professional bodies, statements of values such as codes of conduct, and professional socialization activities such as education and training. Management can be realized through coordination by a special body or an existing central management agency, and through public service conditions, management policies, and practices. Control is assured primarily through a legal framework that enables independent investigation and prosecution, effective accountability and control mechanisms, transparency, public involvement, and scrutiny. The ideal combination and degree of these functions depends on the cultural and political-administrative milieu of the public administration organization (Kettl, 2002, p. 186).

\section{Concluding remarks}

Public administration combines all activities, including military activities, related to the public good and public interest. Public service ethics and integrity are essential to retain public trust, and are a keystone of good governance that transcends conventional public administration. They should underpin public servants' responsibility to exercise stewardship, and to use and develop all resources in the most economical, efficient, and effective way possible.

Military procurement entails a process of identifying, sourcing, and purchasing military material, facilities, and/or logistics from an external source, as deemed necessary to achieve a country's national security strategy. Pure military procurement requires a sensitive procurement approach subject to a regulatory system that acknowledges military confidentiality and strikes a balance between the openness and transparency of the procurement process, on the one hand, and the protection of the core security concerns of the procuring state, on the other.

Ethics refers to well-based standards of right and wrong that prescribe what people ought to do, usually in terms of dimensions such as duties, principles, specific virtues, or benefits to society. For military staff, as public administrators, duty is especially important in the sense that ethics begins with and is grounded in duty. Military staff must serve the public, fulfill the 
expectations of public office, and be trustees of public resources. These are the actions required by their occupation or role, independent of, but reinforced by, other ethical considerations.

In the South African context, there is clearly a need to establish governance networks that can collaborate as the interdependence of a range of individuals and organizations increases. Decision-making should include a wide range of participants who see themselves as legitimate members of the decision-making process, in a context of considerable uncertainty and complexity. From a relational perspective, new ways to collaborate will be open to learning in different ways, and will be able to draw on resources from a range of sources. From an ethical perspective, it is obvious that there is a need for an overarching framework of moral values and ethical principles that can have a significant and sustainable impact on the creation of public value as an outcome of a military procurement process.

A well-functioning ethical framework should underpin a public sector environment that encourages high standards of professional ethics and integrity in military procurement.

\section{References}

Amundsen, I. (2009). Introduction to public sector ethics. Bergen, Norway: Christian Michelsen Institute. Retrieved from https://www.cmi.no/publications/file/3290-introduction-to-public-sector-ethics.pdf

Botha, D. (2010). The arms deal controversy. African Security Review, 12(3), 99-100. doi:10.1080/10246029.2003. 9627240

Chipkin, I., Tshimomolo, G., \& Brunette, R. (2014, August 1). Decentralised procurement fails the state. Mail \& Guardian. Retrieved from http://mg.co.za/article/2014-07-31-decentralised-procurement-fails-the-state

Cox, D., La Caze, M., \& Levine, M. P. (2003). Integrity and the fragile self. Aldershot, UK: Ashgate.

Davis, M. J. (2014). Procurement practices influencing service delivery: A case of Kenya Power. European Journal of Logistics Purchasing and Supply Chain Management, 2(3), 79-137. Retrieved from http://www.eajournals.org/wpcontent/uploads/Procurement-Practices-Influencing-Service-Delivery-A-Case-Of-Kenya-Power2.pdf

Disoloane, V. P. P. (2012). Reception of a code of conduct at the Capricorn district municipality in the Limpopo Province (Unpublished Ph.D. thesis). University of South Africa, Pretoria, South Africa. Retrieved from http:// uir.unisa.ac.za/handle/10500/5897

Fourie, D. J. (2015). Procurement in the South African public service: A reflection of the ethical and legislative framework. Public and Municipal Finance, 4(2), 38-45. Retrieved from https://businessperspectives.org/journals_free/ pmf/2015/PMF_2015_02_Fourie.pdf

Fourie, M. L., \& Opperman, L. (2011). Municipal finance and accounting (2nd ed.). Pretoria, South Africa: Van Schaik.

Hellriegel, D., Jackson, S. E., Scolum, J., Staude, G., Amos, T., Klopper, H. B., Louw, L., \& Oosthuizen, T. (2008). Management (3rd South African ed.). Cape Town, South Africa: Oxford University Press.

Jordaan, J. (2013). Public financial performance management in South Africa: A conceptual analysis (Unpublished $\mathrm{Ph}$. D. thesis). University of Pretoria, Pretoria, South Africa. Retrieved from http://repository.up.ac.za/handle/2263/ 24808

Kazman, J. G., \& Bonczek, S. J. (1999). Ethics in action. Washington, DC: International City/County Management Association.

Kem, J. (2006). The use of the "ethical triangle" in military ethical decision making. Public Administration and Management, 11(1), 22-43. Retrieved from http://spaef.org/article/125/Use-of-the-Ethical-Triangle-in-MilitaryEthical-Decision-Making

Kettl, D. F. (2002). The transformation of governance: Public administration for the twenty-first century (updated ed.). Baltimore, MD: Johns Hopkins University Press.

Lawton, A. (1999). Ethics and management. In A. Rose \& A. Lawton (Eds.), Public services management (pp. 299-300). Harlow, UK: Prentice Hall.

Olshoorn, P. (2011). Military ethics and virtues: An interdisciplinary approach for the 21st century. London, UK: Routledge. doi:10.4324/9780203840825. 
Organisation for Economic Co-operation and Development (OECD) (2000). Trust in government: Ethics measure in OECD countries. Paris, France: OECD. doi:10.1787/9789264187986-en.

Organisation for Economic Co-operation and Development (OECD). (2009). Principles for integrity in public procurement. Paris, France: OECD. doi:10.1787/9789264056527-en.

Organisation for Economic Co-operation and Development (OECD). (2011). Support for improvement in governance and management: Defence procurement. Paris, France: OECD. doi:10.1787/23109246.

Pauw, J. C., \& Wolvaardt, J. S. (2009). Multi-criteria decision analysis in public procurement-A plan from the South. Politeia, 26(1), 66-88. Retrieved from http://uir.unisa.ac.za/bitstream/handle/10500/2899/pauw5.pdf

Republic of South Africa (RSA). (1996a). Constitution of the Republic of South Africa, 108 of 1996. Pretoria, South Africa: Government Printer. Retrieved from http://www.gov.za/sites/www.gov.za/files/images/a108-96.pdf

Republic of South Africa (RSA). (1996b). Defence White Paper. Pretoria, South Africa: Government Printer. Retrieved from http://www.dod.mil.za/documents/WhitePaperonDef/whitepaper\%20on\%20defence1996.pdf

Republic of South Africa (RSA). (1999a). Public finance management act 1 of 1999 (PFMA). Pretoria, South Africa: Government Printer. Retrieved from http://www.treasury.gov.za/legislation/pfma/act.pdf

Republic of South Africa (RSA). (1999b). White Paper on defence-related industries. Pretoria, South Africa: Government Printer. Retrieved from http://www.dod.mil.za/documents/WhitePaperonDef/white\%20paper\%20on $\% 20$ the $\% 20$ SA $\% 20$ defence $\% 20$ related \%20industries1999.pdf

Republic of South Africa (RSA). (2000a). Preferential procurement policy framework act 5 of 2000 (PPPFA). Pretoria, South Africa: Government Printer. Retrieved from http://www.treasury.gov.za/legislation/pfma/supplychain/ PPPFA.pdf

Republic of South Africa (RSA). (2000b). Promotion of administrative justice act 3 of 2000 (PAJA). Pretoria, South Africa: Government Printer. Retrieved from http://www.justice.gov.za/legislation/acts/2000-003.pdf

Republic of South Africa (RSA). (2001). Preferential procurement policy framework regulations (PPPF Regulations). Pretoria, South Africa: Government Printer. Retrieved from http://www.treasury.gov.za/legislation/pfma/ supplychain/gazette_22549.pdf

Republic of South Africa (RSA). (2003). Municipal finance management act 56 of 2003 (MFMA). Pretoria, South Africa: Government Printer. Retrieved from http://www.gov.za/sites/www.gov.za/files/a56-03.pdf

Republic of South Africa (RSA). (2005a). Model policy municipal supply chain management. Pretoria, South Africa: Government Printer. Retrieved from http://mfma.treasury.gov.za/MFMA/Circulars/Circular\%2022/MFMA \% 20 Circular\%20No\%2022\%20-\%20Model \%20Policy\%20Supply \%20Chain \%20Management \%20-\%2025\%20 August \%202005.pdf

Republic of South Africa (RSA). (2005b). Municipal supply chain management regulations. Pretoria, South Africa: Government Printer. Retrieved from http://mfma.treasury.gov.za/MFMA/Regulations\%20and\%20Gazettes/ Municipal \%20Supply\%20Chain\%20Management \%20Regulations\%20-

$\% 20$ Gazette $\% 20$ No $\% 2027636, \% 2030 \% 0$ May $\% 202005$.pdf

Republic of South Africa (RSA), Department of Defence. (1998). The defence review report. Pretoria, South Africa: Government Printer. Retrieved from http://www.dod.mil.za/documents/defencereview/defence\%20review1998.pdf

Republic of South Africa (RSA), Department of Defence. (2014). South African defence review. Pretoria, South Africa: Government Printer. Retrieved from http://www.gov.za/sites/www.gov.za/files/dfencereview_2014.pdf

Republic of South Africa (RSA), National Treasury. (2003). Policy to guide uniformity in procurement reform processes in government. Pretoria, South Africa: Government Printer. Retrieved from http://www.treasury.gov. za/divisions/ocpo/sc/Guidelines/policy.pdf

Republic of South Africa (RSA), National Treasury. (2015). Public sector supply chain management review. Pretoria, South Africa: Government Printer. Retrieved from http://www.gov.za/sites/www.gov.za/files/supplychainmanagementreview_.pdf

Robbins, S. P. (1997). Essentials of organisational behaviour (5th ed.). Upper Saddle River, NJ: Prentice-Hall.

Rolfstam. (2009). Public procurement and innovation: Towards a taxonomy. Journal of Public Procurement, 9(1), 17-56. Retrieved from http://www.ippa.org/IPPC3/JoPP\%209(1)/Art2_TowardsaTaxonomy.pdf

Roodhooft, F., \& Abbeele, A. V. D. (2006). Public procurement of consulting services evidence and comparison with private companies. International Journal of Public Sector Management, 19(5), 490-512. doi:10.1108/ 09513550610677799

Rossouw, D., \& Van Vuuren, L. (2007). Business ethics. Cape Town, South Africa: Oxford University Press.

Sims, R.R. (1994). Ethics and organizational decision making: A call for renewal. London, UK: Quorum Books. 
Singer, P. (2011). Practical ethics (3rd ed.). Cambridge, UK: Cambridge University Press. doi:10.1017/ CBO9780511975950

Stoker, G. (2006). Public value management: A new narrative for networked governance?. American Review of Public Administration, 36(1), 41-57. doi:10.1177/0275074005282583

Sylvester, J., \& Seegers, A. (2008). South Africa's strategic arms package: A critical analysis. Scientia Militaria: South African Journal of Military Studies, 36(1), 52-77. doi:10.5787/36-1-45

Tripodi, P., \& Wolfendale, J. (2011). New wars and new soldiers: Military ethics in the contemporary world. Farnham, UK: Ashgate.

Tukamuhabwa, R. B. (2012). Antecedents and consequences of public procurement non-compliance behavior. Journal of Economics and Behavioral Studies, 4(1), 34-46. Retrieved from http://www.ifrnd.org/Research\%20Papers/J4(1) 4.pdf

Van Baarda, T. A., \& Verweij, D. E. M. (2006). Military ethics: Its nature and pedagogy. In T. A. van Baarda \& D. E. M. Verweij (Eds.), Military ethics: The Dutch approach, a practical guide (pp. 1-24). Leiden, Netherlands, \& Boston, MA: Martinus Nijhoff. doi:10.1163/ej.9789004154407.i-395.6

Wakin, M. M. (2000). Integrity first: Reflections of a military philosopher. Lanham, MD: Lexington Books. 